\title{
Subject Reference Start Date
}

National Cancer Institute

\section{Source}

National Cancer Institute. Subject Reference Start Date. NCI Thesaurus. Code C158689.

The date a subject reference began. 